\title{
A new insertion sequence IS1452 from Acetobacter pasteurianus
}

\author{
Koichi Kondo and Sueharu Horinouchi
}

Author for correspondence: Sueharu Horinouchi. Tel: +81033812 2111 ext. 5123. Fax: +8135802 2931.

Department of

Biotechnology, Division of Agriculture and Life

Sciences, The University of

Tokyo, 1-1-1 Yayoi,

Bunkyo-ku, Tokyo 113, Japan

\begin{abstract}
A new insertion sequence element, IS1452, was found to be associated with inactivation of the alcohol dehydrogenase by insertion in the adhs gene encoding subunit III of the three-component membrane-bound alcohol dehydrogenase complex in Acetobacter pasteurianus. Cloning and sequencing analyses of the mutated subunit III gene locus revealed that IS1452 was inserted at or near the ribosome-binding sequence of adhs. Analysis of transcription using the chloramphenicol acetyltransferase gene as the reporter indicated that IS 1452 abolished transcription of adhs by separating its promoter from the subunit III structural gene. IS1452 was 1411 bp in length and had a terminal inverted repeat of 21 bp. IS1452 contained one long ORF of 416 amino acids rich in basic amino acids. This protein showed homology with a putative transposase, Tra1, of IS701 isolated from the cyanobacterium Calothrix species PCC 7601. Like IS701, IS 1452 was found to generate a 4 bp direct repeat at the site of insertion upon transposition. The target site specificity was rather strict, and a CTA(A or G) sequence appeared to be preferentially recognized. Transposition of IS1452 was replicative, since it was accompanied by an increase in the copy number of IS1452. Several strains belonging to the genus Acetobacter also contained IS1452 at varying copy numbers from one to more than ten. These observations suggest that IS1452 is one of the insertion sequences that are responsible for genetic instability leading to deficiencies in various physiological properties in acetic acid bacteria.
\end{abstract}

Keywords: Acetobacter pasteurianus, insertion sequence, alcohol dehydrogenase, genetic instability

\section{INTRODUCTION}

Acetic acid bacteria are Gram-negative obligately aerobic bacteria consisting of two genera, Acetobacter and Gluconobacter. They are characterized by their ability to oxidize ethanol into acetic acid and their resistance to acetic acid and ethanol (De Ley et al., 1984). Because of these characteristics, Acetobacter spp. are used for the industrial production of vinegar. We have studied the biochemistry and genetics of ethanol oxidation by acetic acid bacteria through purification, characterization and gene cloning of membrane-bound alcohol dehydrogen-

Abbreviations: ADH, membrane-bound alcohol dehydrogenase; CAT, chloramphenicol acetyltransferase; IS, insertion sequence.

The GenBank/EMBLDDBJ accession number for the sequence reported in this paper is D63923. ase (ADH) (Kondo et al., 1995; Takemura et al., 1993b; Tamaki et al., 1991; Tayama et al., 1989), membranebound aldehyde dehydrogenase (ALDH) (Fukaya et al., 1989a, b) and terminal ubiquinol oxidase (Fukaya et al., 1993). ADH of Acetobacter pasteurianus NCI 1380 consists of three components, a $78 \mathrm{kDa}$ alcohol dehydrogenase (subunit I), a $48 \mathrm{kDa}$ cytochrome $c$ (subunit II), and a $20 \mathrm{kDa}$ protein (subunit III). During these studies, we have found that insertion of a $1665 \mathrm{bp}$ insertion sequence (IS), IS1380, into a TCGA sequence within the cytochrome $c$ gene inactivates the ethanoloxidizing ability (Takemura et al., 1991). This type of mutation was observed in most spontaneous mutants found to be deficient in ethanol oxidation. In addition, the copy number of IS1380 in cells of strain NCI 1380 was about 100, and this IS was distributed in several Acetobacter spp. at a similar high copy number. These observations indicate that the observed genetic instabili- 
ties in ethanol oxidation may be explained in terms of IS1380 insertion into the cytochrome $c$ gene.

In addition to the genetic instability in ethanol oxidation in Acetobacter spp., spontaneous mutations resulting in deficiency in acetic acid resistance (Ohmori et al., 1980) and cellulose formation (Cook \& Colvin, 1980; Steel \& Walker, 1957) arise at high frequencies. Investigations have revealed that insertion sequences, such as IS1031s (from IS1031A to IS1031D) and IS1032, participate in the inactivation of several genes (Coucheron, 1991, 1993; Iversen et al., 1994). It is thus apparent that multiple insertion sequences play a major role in generating spontaneous mutations leading to deficiencies in various physiological properties.

In the present study with A. pasteurianus NCI 1452, we found a new insertion sequence, named IS1452, in the $\mathrm{ADH}$ subunit III $(a d h S)$ gene in spontaneous mutants deficient in ethanol oxidation. Subunit III is required for enzyme activity of the three-component type ADH (Kondo et al., 1995). This paper describes the characterization and sequencing of IS1452. It is present as multiple copies in A. pasteurianus and distributed in several Acetobacter spp. It is therefore likely that IS1452 is another type of IS that can cause spontaneous mutations at high frequencies in acetic acid bacteria.

\section{METHODS}

Bacterial strains and plasmids. All of the bacterial strains and plasmids used are listed in Table 1. A. pasteurianus NCI 1452, a restriction-deficient mutant, was isolated from $A$. pasteurianus NCI 1380 by NTG treatment (Takemura et al., 1993b).

Media and culture conditions. YPG medium (pH 6.5) consisted of $5 \mathrm{~g}$ yeast extract (Wako Pure Chemicals), $2 \mathrm{~g}$ polypeptone (Wako), and $30 \mathrm{~g}$ glucose in 11 water. Each strain of acetic acid bacteria was first cultured in a $50 \mathrm{ml}$ test tube containing $5 \mathrm{ml}$ YPG medium with shaking for $24-40 \mathrm{~h}$ at $30^{\circ} \mathrm{C}$. From 1 to $5 \mathrm{ml}$ of the broth was inoculated into $100 \mathrm{ml}$ YPG medium in a $500 \mathrm{ml}$ shaking flask and further cultured with shaking at $30^{\circ} \mathrm{C}$. When necessary, ethanol at a final concentration of $3 \%(\mathrm{v} / \mathrm{v})$ was added to the medium at the start of the culture. Escherichia coli strains were routinely cultured in Luria broth (Sambrook et al., 1989). When necessary, ampicillin was added to the medium at a final concentration of $50 \mu \mathrm{g} \mathrm{ml}^{-1}$.

DNA preparation and manipulation. Total DNA of acetic acid bacteria was prepared as described by Okumura $e t$ al. (1985). DNA-DNA hybridization was performed by standard methods (Sambrook et al., 1989; Southern, 1975) with a nylon membrane (Hybond- $\mathrm{N}^{+}$; Amersham International). $\left[\alpha^{-32} \mathrm{P}\right] \mathrm{dCTP}$ at $3 \mathrm{kCi} \mathrm{mmol}{ }^{-1}$ (111 TBq $\left.\mathrm{mmol}^{-1}\right)$ for the Multiprime DNA labelling system was purchased from Amersham. Restriction endonucleases, Klenow fragment, Taq DNA polymerase, T4 DNA polymerase and T4 DNA ligase were purchased from Takara Shuzo. E. coli was transformed as described by Hanahan (1983). Acetobacter strains were transformed by electroporation as described by Wong $e t$ al. (1990). Nucleotide sequences were determined by the dideoxy chain-termination method (Sanger et al., 1977) combined with the M13 cloning system (Yanisch-Perron et al., 1985) on a DSQ-1 (Shimadzu) DNA sequencer. General recombinant DNA techniques were as described by Sambrook et al. (1989).
Determination of the target site of IS1452. The 3.5 and $4.0 \mathrm{~kb}$ EcoRV fragments, which had been shown by Southern hybridization to contain IS1452, were cloned from the total DNA of mutant m00-09 into the SmaI site of pUC18. The recombinant plasmids possessing these fragments were used as templates for amplification with Taq DNA polymerase by PCR of the region covering the target site of IS1452. Four primers used were: IS1452-N-primer (5'-CCGAATTCCAGCGTCTCTTCAACAG-3', which extends from nt 98 to 77 of IS1452 (see Fig. 2), with three bases added to the $5^{\prime}$-end of the oligonucleotide to generate an EcoRI site); IS1452-C-primer (5'-AAAGCTTGCACAACGCAGACTACCC-3', which extends from nt 1299 to 1319 , with four bases added to the $5^{\prime}$-end of the oligonucleotide to generate a HindIII site); M13-47 (5'CGCCAGGGTTTTCCCAGTCACGAC-3'); and RV-M (5'GAGCGGATAACAATTTCACACAGG-3'). IS1452-N- and IS1452-C-primers were synthesized on an Expedite Nucleic Acid Synthesis System DNA synthesizer (PerSeptive Biosystems). M13-47 and RV-M were sequencing primers purchased from Takara Shuzo. The fragments amplified by PCR with the appropriate sets of primers were then cloned onto pUC18 and their nucleotide sequences covering both ends of IS1452 were determined. Five of each clone bearing the respective fragments were randomly picked up and independently sequenced.

Promoter assays. Cell extracts were prepared with an ultrasonifier (Branson Sonifier cell disrupter 250) from mid- or lateexponential-phase cells suspended in $10 \mathrm{mM}$ potassium phosphate buffer ( $\mathrm{pH} \mathrm{6.0)}$. Chloramphenicol acetyltransferase (CAT) activity was measured as described by Shaw (1975). We used pMVC18, an Acetobacter-E. coli shuttle-plasmid carrying a promoterless CAT gene, for promoter-probing experiments (Takemura et al., 1993b). DNA fragments to be tested were prepared from pADSm911 containing the originally cloned IS1452 sequence and they were inserted in the SmaI site on pMVC18 for the promoter assays. Plasmids pMVC18-m1 and pMVC18-m2 (see Fig. 4) contained the $0.16 \mathrm{~kb}$ SphI-NheI fragment of pADSm911, which had been blunt-ended by T4 DNA polymerase, in the SmaI site of pMVC18 in the same orientation as and the opposite orientation to that of the CAT gene, respectively. Similarly, pMVC18-m 3 and pMVC18-m4 were constructed using the $0.66 \mathrm{~kb} S p h \mathrm{I}$ fragment, and pMVC18-m5 and pMVC18-m6 were constructed using the $0.5 \mathrm{~kb}$ NheI-SphI fragment. For construction of pMVC18-m7 and pMVC18-m8, the $1.6 \mathrm{~kb} S p h \mathrm{I}-S p l \mathrm{I}$ fragment was obtained by PCR with the $S p h$ I-side-primer [ $5^{\prime}$-GTGGATCCGCTTATGCCCCGGCCAAGGCCAGTC-3', which extends nt 1-31 of the adbS gene (Kondo et al., 1995), with two bases added to the 5 '-end of the oligonucleotide and with two bases changed (underlined) to change the $S p h I$ site into a BamHI site], and the SplI-side-primer (5'-GACAGGGCACGTACGGCAATCAGTTTCATTCAG-3', which extends from nt 201 to 168). Plasmid pMVC18-ADH, containing the promoter of $a d b$ at the $S m a$ I site (Takemura et al., 1993b), was used as a positive control of this assay.

Computer-aided analysis of nucleotide and amino acid sequences. The DNA sequence was analysed by using the GENETYX sequence analysis program (Software Development). DNA and amino acid sequence homology searches were performed at the National Center for Biotechnology Information (NCBI) using the BLAST network service (Altschul et al., 1990). 
Table 1. Bacterial strains and plasmids

\begin{tabular}{|c|c|c|}
\hline Strain/plasmid & Relevant characteristics* & Reference/source \\
\hline \multicolumn{3}{|l|}{ Strains } \\
\hline \multicolumn{3}{|l|}{ Acetobacter pasteurianus } \\
\hline NCI 1452 & $\begin{array}{l}\mathrm{Sm}^{\mathrm{r}} \text {, met, thermophilic, restriction-deficient } \\
\text { mutant of NCI } 1452\end{array}$ & Takemura et al. $(1993 a, b)$ \\
\hline $\mathrm{m} 00-09$ & $\begin{array}{l}\text { Reduced ADH activity (subunit III deficient); } \\
\text { spontaneous mutant of NCI } 1452\end{array}$ & Kondo et al. (1995) \\
\hline $\mathrm{m} 00-12, \mathrm{~m} 00-14, \mathrm{~m} 12-10, \mathrm{~m} 12-20$ & $\begin{array}{l}\text { Reduced ADH activity (subunit III deficient); } \\
\text { spontaneous mutants of NCI } 1452\end{array}$ & This work \\
\hline NCIB 7214 & Wild-type & NCIB \\
\hline \multicolumn{3}{|l|}{ Acetobacter aceti } \\
\hline No. 1023 & Thermophilic & Ohmori et al. (1980) \\
\hline IFO 3284 & Wild-type & IFO \\
\hline Acetobacter xylinum NCIB 11664 & Wild-type & NCIB \\
\hline Acetobacter liquefaciens IFO 12388 & Wild-type & IFO \\
\hline Acetobacter hansenii NCIB 8746 & Wild-type & NCIB \\
\hline Acetobacter diazotrophicus ATCC 49037 & Wild-type & ATCC \\
\hline Acetobacter polyoxogenes NCI 1028 & Wild-type & Entani et al. (1985) \\
\hline Gluconobacter oxydans ATCC 19357 & Wild-type & IFO \\
\hline Gluconobacter suboxydans IFO 12528 & Wild-type & ATCC \\
\hline Gluconobacter asaii IFO 3276 & Wild-type & IFO \\
\hline Gluconobacter cerinus IFO 3267 & Wild-type & IFO \\
\hline Escherichia coli JM109 & $\begin{array}{l}\text { recA1 end } 11 \text { gyrA96 thi hsdR17 supE44 relA1 } \\
\Delta(\text { lac-pro } A B) / F\left[\text { traD36 proAB } \text { lacl }^{4} \text { lacZ } \Delta \mathrm{M} 15\right]\end{array}$ & Yanisch-Perron et al. (1985) \\
\hline \multicolumn{3}{|l|}{ Plasmids } \\
\hline pUC18 & $\mathrm{Ap}^{\mathrm{r}}, \operatorname{lac}^{\prime}$ & Yanisch-Perron et al. (1985) \\
\hline pMV24 & $\mathrm{Ap}^{\mathrm{r}}$, lac $\mathrm{Z}^{\prime} ;$ Acetobacter $-E$. coli shuttle vector & Fukaya et al. (1989b) \\
\hline pMVC18 & $\begin{array}{l}\mathrm{Ap}^{\mathrm{r}}, \text { Acetobacter }-E \text {. coli } \text { shuttle vector containing } \\
\text { a promoterless CAT gene }\end{array}$ & Takemura et al. (1991) \\
\hline pADSm911 & $\begin{array}{l}\mathrm{Ap}^{\mathrm{r}} \text {, containing an IS1452-inactivated adhS gene } \\
\text { on pUC18 }\end{array}$ & This work \\
\hline
\end{tabular}

"Ap ${ }^{\mathrm{r}}$, ampicillin resistance; $\mathrm{Sm}^{\mathrm{r}}$, streptomycin resistance.

\section{RESULTS AND DISCUSSION}

\section{Isolation and cloning of the mutated adhs gene}

In our previous work (Kondo et al., 1995), we demonstrated that the smallest $20 \mathrm{kDa}$ subunit (subunit III) was essential for the enzymic activity of three-component $\mathrm{ADH}$ from $A$. pasteurianus. During this study, we characterized various spontaneous mutants which lacked the ethanol-oxidizing ability. One of the mutant strains, m00-09, lacked subunit III ( $a d b S)$, as determined by immunoblotting with anti-subunit III antibody, and introduction of the $a d b S$ gene on a plasmid into mutant m00-09 caused production of subunit III (Kondo et al., 1995). Hybridization of EcoRV digests of the chromosomal DNA from mutant m00-09 with the adhS probe revealed that the positive hybridization signal $(6.5 \mathrm{~kb})$ was larger than the expected $5.0 \mathrm{~kb}$ (Fig. 1a, b). This suggested that the mutation of strain m00-09 was due to an insertion and not a point mutaion. The restriction map of the cloned $6.5 \mathrm{~kb}$ fragment showed that a $1.5 \mathrm{~kb}$ DNA sequence was inserted somewhere between the SphI and PstI sites in the first half of the gene (Fig. 1b).
We next examined the presence of the $1.5 \mathrm{~kb}$ fragment in the adhS gene sequence in other mutants deficient in production of subunit III. Four such mutants among our collection gave the same Southern hybridization pattern (Fig. 1a), suggesting that they had the same insertion as mutant m00-09.

\section{Nucleotide sequence of IS1452}

After determining the nucleotide sequence covering the ATG codon as well as the whole $a d b S$ gene, the $1.5 \mathrm{~kb}$ fragment was found to be inserted at or near the ribosome-binding sequence of $a d b S$ (Fig. 6) with a duplication of $4 \mathrm{bp}$ (CTAG) at the target site. The inserted fragment was 1411 bp long and was bounded by a perfect 21 bp inverted repeat (Fig. 2). The nucleotide sequence of the coding region of $a d h S$ was the same as that determined for the parental strain, indicating that the mutant phenotype resulted from the insertion alone. There is one long ORF within the insertion (ORF416) starting with ATG (nt 46-48) and terminating with TAA (nt 1294-1296), encoding 416 amino acids with a 
(a)

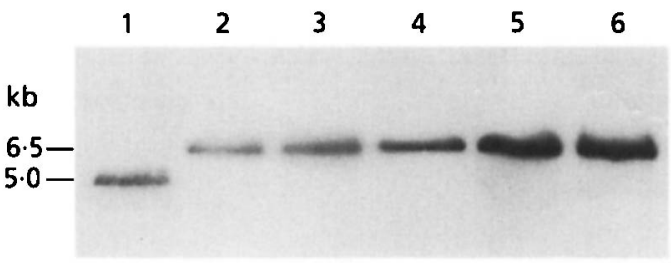

(b)

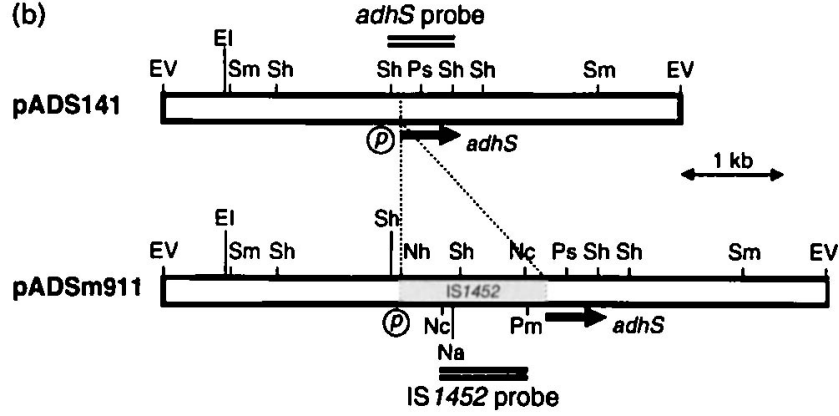

Fig. 1. Detection of an insertion sequence in the adhs gene by Southern blot hybridization (a) and restriction maps of the adhs genes cloned from the parental strain (PADS141) and mutant strain m00-09 (pADSm911) (b). (a) The EcoRV-digested chromosomal DNA from the parental strain gives a $5.0 \mathrm{~kb}$ positive signal when probed with a 32 p-labelled $0.7 \mathrm{~kb} S p h \mathrm{l}$ fragment (lane 1). Similar hybridization experiments with the chromosomal DNAs from mutant strains m00-09 (lane 2), m0012 (lane 3), m00-14 (lane 4), m12-10 (lane 5) and m12-20 (lane 6) show a $6.5 \mathrm{~kb}$ signal, suggesting the presence of an is of $1.5 \mathrm{~kb}$. (b) The $6.5 \mathrm{~kb}$ fragment from mutant m00-09 was cloned and its restriction map was constructed. The precise insertion point of a $1.5 \mathrm{~kb}$ fragment adjacent to the adhs gene was determined by nucleotide sequencing. The arrows indicate the location and direction of adhs. The promoter of adhs is indicated by a circled ' $p$ '. The probes used for hybridization are indicated by double heavy bars. Restriction enzymes: El, EcoRI; EV, EcoRV; Na, Nael; Nc, Ncol; Nh, Nhel; Pm, PmaCl; Ps, Pstl; Sh, Sphl; Sm, Smal.

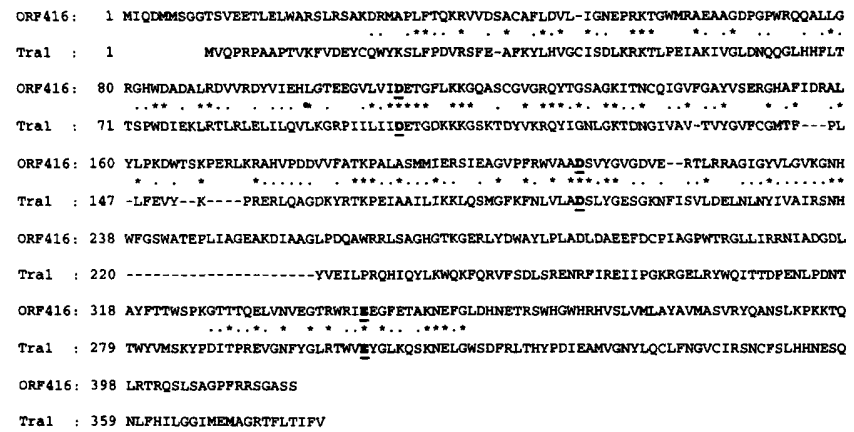

Fig. 3. Comparison of amino acid sequences of the putative transposases on IS1452 (ORF416) and IS701 (Tra1). Identical and conserved residues are indicated by asterisks and stops, respectively. The amino acids that probably form a DDE motif are indicated by underlined bold letters.

calculated molecular mass of $46 \mathrm{kDa}$. ORF416 shows considerable similarity in amino acid sequence to Tra1 (Fig. 3), a probable transposase of IS701 from the cyanobacterium Calothrix sp. PCC 7601 (Mazel et al., 1991). These two proteins show about $30 \%$ identity in the primary sequence, especially in the $\mathrm{NH}_{2}$-terminal regions. Both transposases contain a DDE motif (Fig. 3) which is conserved among bacterial IS transposases and retroviral/retrotransposon integrases as proposed by Kulkosky et al. (1992) and Grindley \& Leschzinner (1995). Like other transposases (Galas \& Chandler, 1989), ORF416 is rich in basic amino acids.

All of the above observations indicate that the DNA insert is a new IS element of A. pasteurianus. We named it IS1452 and registered it in the Plasmid Reference Center (Stanford, CA, USA) (Lederberg, 1987).

\section{Promoter activity analysis of IS1452 and adhS}

Insertion of IS1452 between the promoter region and the non-mutated coding region of the adhS gene in m00-09 suggested that it had interrupted expression of the $a d b S$ gene at the transcriptional level. Hence we assessed promoter activities of several regions in the $2.5 \mathrm{~kb} \mathrm{SphI}$ fragment (Fig. 4) using the CAT gene on pMVC18 as a reporter gene. Previous work (Kondo et al., 1995) has shown the presence of the promoter of adhS to be downstream of the SphI site. Recombinant reported constructs from pMVC18-m1 to pMVC18-m8 were introduced into A. pasteurianus NCI 1452 by electroporation (Wong et al., 1990), and the CAT activities of the transformants are summarized in Fig. 4. The adhS promoter in pMVC18- $\mathrm{m} 1$ showed a one-order lower activity than the $a d h$ promoter in $\mathrm{pMVC} 18-\mathrm{ADH}$ as a positive control. It is apparent that transcription of the adbS-encoding sequence in pMVC18-m7 is almost completely abolished, due to a polar effect of IS1452 inserted between the promoter and the ATG start codon. The transcriptional read-through of the ORF416 sequence from the adhS promoter in pMVC18-m3 is detected, although the activity is somewhat reduced.

Fig. 2. Nucleotide sequence of 151452 and deduced amino acid sequence of ORF416. Terminal inverted-repeat sequences are indicated by opposing arrows. Primer sequences for amplification of the target sites of IS1452 are indicated by dotted underlines. 

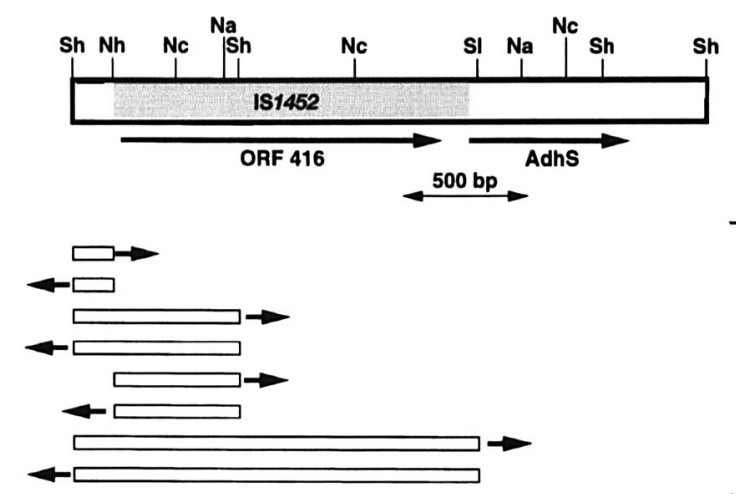

Fig. 4. Construction of plasmids for transcriptional assays and promoter activities of indicated fragments. The restriction map of the $2.5 \mathrm{~kb} S p h l$ fragment including the adhS gene and IS1452 from A. pasteurianus m00-09 is shown at the top. Each fragment from $\mathrm{m} 1$ to $\mathrm{m} 8$ was inserted into the Smal site of pMVC18 (Takemura et al., 1993b), resulting in plasmids PMVC-m1 to $-\mathrm{m} 8$. Short arrows indicate the direction of transcription of the CAT gene. CAT activity of the transformants cultured in the presence of ethanol was assayed as described in Methods. pMV18-ADH is a positive clone control and pMV18 is the vector negative control. Restriction enzymes: Na, Nael; Nc, Ncol; Nh, Nhel; Sh, Sphl; SI, Sp/l.
The low CAT activity from pMVC18-m5 may be due to the promoter for the ORF416 transposase protein. However, the low activity is in agreement with the observations that the expression of transposases is generally weak (Galas \& Chandler, 1989). Although strong transcriptional activity in the opposite orientation to that of the transposases is observed in several IS elements, such as IS10R (Kleckner, 1989) and IS1186 (Podglajen et al., 1994), this is not the case for IS1452. The fragment in pMVC18-m6 shows little or no outward promoter activity.

\section{Replicative transposition of IS1452}

Most IS elements are present at a multiple copy number in a cell (Galas \& Chandler, 1989). To estimate the copy number of IS1452 in the parental strain (NCI 1452) and mutant strain (m00-09), we carried out Southern blot analysis against the restriction digests of total DNA of the two strains by using a $0.7 \mathrm{~kb} \mathrm{Ncol}$ fragment as the probe (Fig. 1b). To obtain the precise copy number, we digested the chromosomal DNAs with three different restriction enzymes, NcoI, EcoRV and SphI. The NcoIdigest of the chromosomal DNA from the parental strain gave a single hybridization signal of $0.7 \mathrm{~kb}$ (Fig. 5 , lane 1). The EcoRV-digest gave five signals (lane 2), indicating the presence of five copies of IS1452 in the parental strain, since EcoRV does not cleave the IS1452encoding sequence. This was confirmed by the experiment with $S p h$ I which cleaves it into two; there are ten signals in the $S p h$ I-digest (lane 3). The copy number of IS1452 in strain NCI 1380, the parental strain of NCI 1452, was also determined to be five (data not shown).

On the other hand, the copy number of IS1452 in mutant m00-09 was calculated to be six, because the EcoRVdigest of total DNA from this mutant gave six positive signals (lane 4) and the SphI-digest gave 12 signals (lane 5). It is evident that transposition of IS1452 is accompanied by an increase in the copy number of the transposon. Since no change in electrophoretic mobilities of the original ten bands in the SphI-digests is

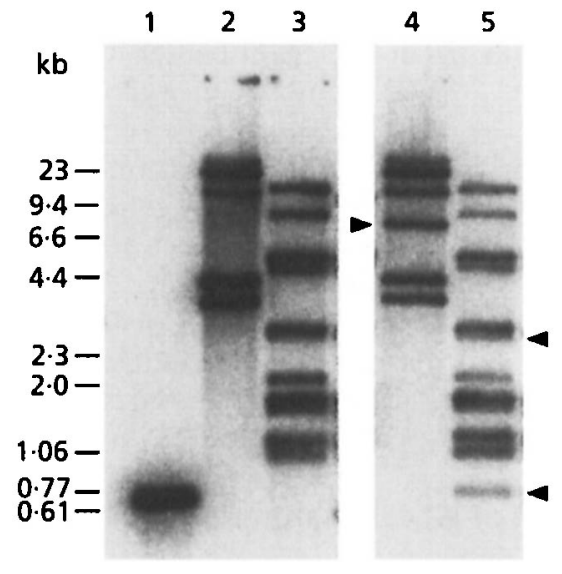

Fig. 5. Copy number analysis of IS1452 by Southern blot hybridization. The total DNAs from A. pasteurianus NCI 1452 (parental) and mutant strain m00-09 were probed with a ${ }^{32} \mathrm{p}$ labelled $0.7 \mathrm{~kb}$ Ncol fragment within the IS 1452 sequence. The total DNA from strain NCl 1452 (left panel) was digested with Ncol (lane 1), EcoRV (lane 2), and Sphl (lane 3). The total DNA from mutant m00-09 (right panel) was digested with EcoRV (lane 4) and Sphl (lane 5). Arrowheads indicate the bands observed only in the mutant strain.

observed, a newly copied IS1452 presumably inserts at the new site, whereas the template IS1452 remains at the original site. We therefore conclude that transposition of IS1452 is replicative. Replicative transposition was also observed for the four mutations by IS1452 deficient in production of subunit III as described above (data not shown).

\section{Target site specificity of IS1452}

To determine the target site specificity, we cloned the 3.5 and $4.0 \mathrm{~kb}$ EcoRV fragments giving a positive signal in DNA-DNA hybridization with the IS1452 sequence (Fig. 1b) as probe. Nucleotide sequencing of the regions containing the target sites showed that both contained a 


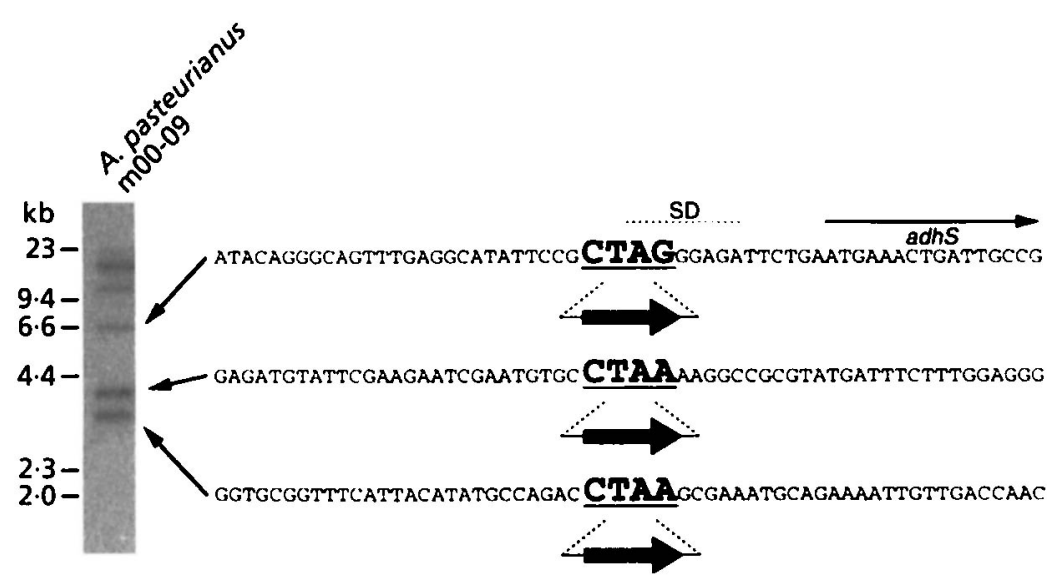

Fig. 6. Determination of the target sites of IS1452 and the adjacent nucleotide sequences in $A$. pasteurianus m00-09. The target sites of IS1452 in the indicated fragments giving a positive signal by Southern hybridization are shown by underlined bold letters. Southern blot hybridization was carried out between the EcoRV-digested total DNA from mutant m00-09 and a ${ }^{32}$-labelled $0.7 \mathrm{~kb} \quad \mathrm{Ncol}$ fragment within the 151452 sequence. The IS1452 in the adhs gene was contained in the $6.5 \mathrm{~kb}$ fragment. Thin arrow indicates the $\mathrm{NH}_{2}$-terminal region and its direction of adhs. A probable ribosome-binding (SD) sequence (Shine \& Dalgarno, 1974) of adhs is marked. Heavy arrows indicate the direction of ORF416.

target site duplication of $4 \mathrm{bp}$, CTAA (Fig. 6). The duplication of CTAA is the same as that observed for the insertion of IS701 in the cyanobacterium Calothrix sp. (Mazel et al., 1991). This is in agreement with the similarity of the putative transposases encoded by IS1452 and IS701, because the target repeat reflects the characteristics of transposases involved in generating staggered cuts as an early event in transposition. It is therefore apparent that the target site specificity of IS1452 may be relatively strict, and that a CTA(A or $G)$ sequence may be preferentially recognized. The nucleotide sequences outside the IS1452 sequence suggested that the copies in the 3.5 and $4.0 \mathrm{~kb}$ fragments do not disrupt any ORFs.

\section{Distribution of IS1452 in other acetic acid bacteria}

To investigate the distribution of IS1452 in other acetic acid bacteria, we performed Southern blot analysis against EcoRV-digested total DNAs from a number of acetic acid bacteria by using the $0.7 \mathrm{~kb} \mathrm{Ncol}$ fragment in the IS1452 sequence (Fig. 1b) as probe; the results are shown in Fig. 7. A. pasteurianus, Acetobacter aceti and Acetobacter hansenii were found to contain IS1452. In comparison with that of IS1380 (Takemura et al., 1991), the copy numbers of IS1452 in these species were relatively low, varying from one to at least ten. IS1380 is present in several Acetobacter spp. at a high copy number of approximately 100 . The distribution pattern of IS1452 among acetic acid bacteria is also different from that of IS1380 (Takemura et al., 1991). Acetobacter xylinum and Acetobacter polyoxogenes possess IS1380 but do not possess IS1452. A. hansenii does not possess IS1380 but possesses IS1452.

\section{Comparison between IS1452 and IS1380}

IS1452 of $1411 \mathrm{bp}$ in length with a terminal inverted repeat of $21 \mathrm{bp}$ encodes a putative transposase of 416 amino acids, and IS1380 of 1665 bp in length with a $15 \mathrm{bp}$ terminal repeat encodes a putative transposase of 461 amino acids. The copy number of IS1452 is rather low, in comparison with that of IS1380 whose copy number is about 100 . The former generates a 4 bp [CTA(A or G)] duplication at the site of insertion,

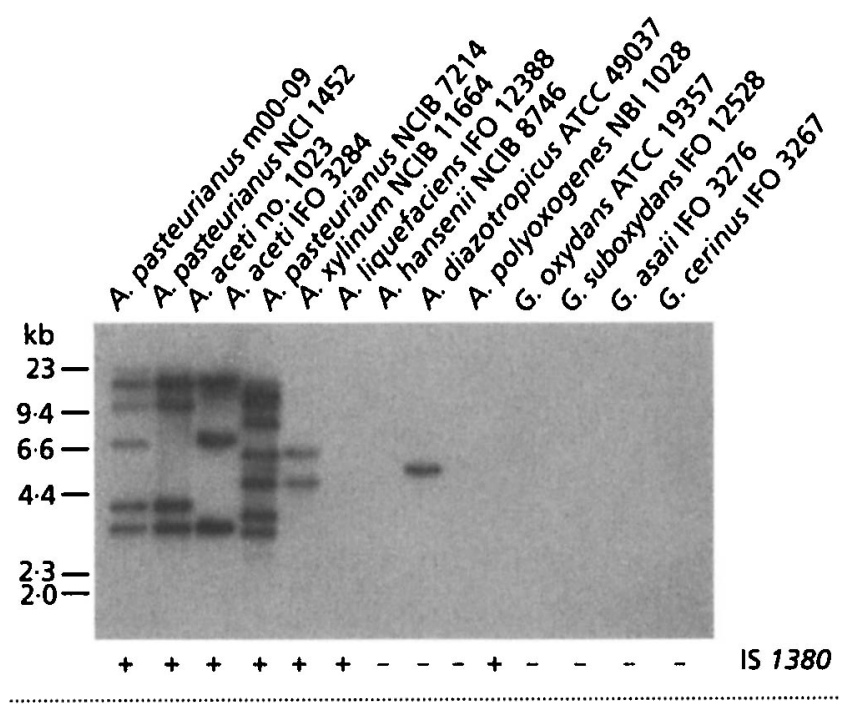

Fig. 7. Distribution of IS1452 in acetic acid bacteria. Southern blot hybridization of a ${ }^{32} \mathrm{P}$-labelled $0.7 \mathrm{~kb} \mathrm{Ncol}$ fragment within the IS1452 sequence against EcoRV-digested chromosomal DNA from each strain is shown. The presence $(+)$ and absence $(-)$ of IS1380 in each strain is indicated under the autoradiogram.

whereas the latter generates a different 4 bp duplication (TCGA). The difference in target site specificity might reflect the lack of amino acid sequence similarity. The wide distribution of both IS1452 and IS1380 among acetic acid bacteria suggests that they may have spread by horizontal gene transfer. Furthermore, the similarity in amino acid sequence of the putative transposases of IS1452 and IS701 and their same target specificity might suggest the possibility that horizontal gene transfer has occurred between Acetobacter and the cyanobacterium Calothrix.

\section{Conclusions}

Spontaneous mutations at high frequencies in strains of the genus Acetobacter, affecting various physiological properties such as acetic acid resistance (Ohmori et al., 1982), ethanol oxidation (Ohmori et al., 1982; Take- 
mura et al., 1991), and cellulose production (Cook \& Colvin, 1980), have been observed. Our study on the genetic instability of ethanol oxidation in A. pasteurianus has led to the discovery of IS1452 which inserts in and disrupts the adbS gene, in addition to IS1380 which disrupts the cytochrome $c$ gene (Takemura et al., 1991). The present study showed that all of the five mutants deficient in production of subunit III contained IS1452 in the adbS gene. In addition, $10-60 \%$ of the alcohol dehydrogenase-deficient mutants obtained spontaneously from the culture in the late stationary phase contained IS1380 in the cytochrome $c$ gene (unpublished results). The frequent transposition of these transposons observed as insertions in mutants deficient in ethanol oxidation suggests that these indigenous IS elements are responsible for the genetic instability. Although transposition of IS1380 seems to be induced in the late growth stage when the concentration of acetic acid in the medium is increased (Takemura et al., 1991), the mechanism for induction of the transposition of IS1380 as well as IS1452 is still unclear.

In addition to IS1452 and IS1380 associated with inactivation of ethanol oxidation in A. pasteurianus, a family of IS1031 elements including IS1032 are known to inactivate cellulose and exopolysaccharide production in A. xylinum (Coucheron, 1991, 1993; Iversen et al., 1994). The IS1031 family generate a 3 bp target sequence duplication (TNA, where $\mathrm{N}$ represents $\mathrm{G}, \mathrm{T}$ or $\mathrm{C}$ ) upon transposition. It is thus apparent that the genetic instability in the genus Acetobacter can be ascribed, in most cases, to transposition of multiple indigenous IS elements with multiple copies.

\section{REFERENCES}

Altschul, S. F., Gish, W., Miller, W., Myers, E. W. \& Lipman, D. J. (1990). Basic local alignment search tool. J Mol Biol 215, 403-410.

Cook, K. E. \& Colvin, J.R. (1980). Evidence for a beneficial influence of cellulose production on growth of Acetobacter xylinum in liquid medium. Curr Microbiol 3, 203-205.

Coucheron, D. H. (1991). An Acetobacter xylinum insertion sequence element associated with inactivation of cellulose production. J Bacteriol 173, 5723-5731.

Coucheron, D. H. (1993). A family of IS1031 elements in the genome of Acetobacter xylinum: nucleotide sequences and strain distribution. Mol Microbiol 9, 211-218.

De Ley, J., Swings, J. \& Gossele, F. (1984). Key to the genera of the family Acetobacteraceae. In Bergey's Manual of Systematic Bacteriology, vol. 1, pp. 268-278. Edited by N. R. Krieg \& J. G. Holt. Baltimore: Williams \& Wilkins.

Entani, E., Ohmori, S., Masai, H. \& Suzuki, K. (1985). Acetobacter polyoxogenes sp. nov., a new species of an acetic acid bacterium useful for producing vinegar with high acidity. J Gen Appl Microbiol 31, 475-490.

Fukaya, M., Tayama, K., Okumura, H., Kawamura, Y. \& Beppu, T. (1989a). Purification and characterization of membrane-bound aldehyde dehydrogenase from Acetobacter polyoxogenes sp. nov. Appl Microbiol Biotechnol 32, 176-180.

Fukaya, M., Tayama, K., Tamaki, T., Tagami, H., Okumura, H., Kawamura, Y. \& Beppu, T. (1989b). Cloning of membrane-bound aldehyde dehydrogenase gene of Acetobacter polyoxogenes and improvement of acetic acid production by use of the cloned gene. Appl Environ Microbiol 55, 171-176.

Fukaya, M., Tayama, K., Tamaki, T., Ebisuya, H., Okumura, H., Kawamura, Y., Horinouchi, S. \& Beppu, T. (1993). Characterization of a cytochrome $a_{1}$ that functions as a ubiquinol oxidase in Acetobacter aceti. J Bacteriol 175, 4307-4314.

Galas, D. J. \& Chandler, M. (1989). Bacterial inserticn sequences. In Mobile DNA, pp. 109-162. Edited by D. E. Berg \& M. M. Howe. Washington, DC: American Society for Microbiology.

Grindley, N. D. F. \& Leschziner, A. E. (1995). DNA transposition: from a black box to a color monitor. Cell 83, 1063-1066.

Hanahan, D. (1983). Studies on transformation of Escherichia coli with plasmids. $J \mathrm{Mol}$ Biol 166, 557-580.

Iversen, T.-G., Standal, R., Pedersen, T. \& Coucheron, D. H. (1994). IS1032 from Acetobacter xylinum, a new mobile insertion sequence. Plasmid 32, 46-54.

Kleckner, N. (1989). Transposon Tn10. In Mobile DNA, pp. 227-268. Edited by D. E. Berg \& M. M. Howe. Washington, DC: American Society for Microbiology.

Kondo, K., Beppu, T. \& Horinouchi, S. (1995). Cloning, sequencing, and characterization of the gene encoding the smallest subunit of the three-component membrane-bound alcohol dehydrogenase from Acetobacter pasteurianus. J Bacteriol 177, 5048-5055.

Kulkosky, J., Johns, K. S., Katz, R. A., Mack, J. P. G. \& Skalka, A. M. (1992). Residues critical for retroviral integrative recombination in a region that is highly conserved among retroviral/ retrotransposon integrases and bacterial insertion sequence transposases. Mol Cell Biol 12, 2331-2338.

Lederberg, E. M. (1987). Plasmid reference center registry of transposon (Tn) and insertion sequence (IS) allocations through December 1986. Gene 51, 115-118.

Mazel, D., Bernard, C., Schwarz, R., Castets, A. M., Houmard, J. \& Tandeau de Marsac, N. (1991). Characterization of two insertion sequences, IS701 and IS702, from the cyanobacterium Calothrix species PCC 7601. Mol Microbiol 5, 2165-2170.

Ohmori, S., Masai, H., Arima, K. \& Beppu, T. (1980). Isolation and identification of acetic acid bacteria for submerged acetic acid fermentation at high temperature. Agric Biol Chem 44, 29012906.

Ohmori, S., Uozumi, T. \& Beppu, T. (1982). Loss of acetic acid resistance and ethanol oxidizing ability in an Acetobacter strain. Agric Biol Chem 46, 381-389.

Okumura, H., Uozumi, T. \& Beppu, T. (1985). Construction of plasmid vector and genetic transformation system for Acetobacter aceti. Agric Biol Chem 49, 1011-1017.

Podglajen, I., Breuil, J. \& Collatz, E. (1994). Insertion of a novel DNA sequence, IS1186, upstream of the silent carbapenemase gene $c f i$, promotes expression of carbapenem resistance in clinical isolates of Bacteroides fragilis. Mol Microbiol 12, 105-114.

Sambrook, J., Fritsch, E. F. \& Maniatis, T. (1989). Molecular Cloning: a Laboratory Manual, 2nd edn. Cold Spring Harbor, NY: Cold Spring Harbor Laboratory.

Sanger, F., Nicklen, S. \& Coulson, A. R. (1977). DNA sequencing with chain-terminating inhibitors. Proc Natl Acad Sci USA 74, 5463-5467.

Shaw, W. V. (1975). Chloramphenicol acetyltransferase from chloramphenicol-resistant bacteria. Methods Enzymol 43, 737754.

Shine, J. \& Dalgarno, L. (1974). The 3 '-terminal sequence of Escherichia coli $16 \mathrm{~S}$ ribosomal RNA: complementarity to non- 
sense triplets and ribosome-binding sites. Proc Natl Acad Sci USA 71, 1342-1346.

Southern, E. M. (1975). Detection of specific sequences among DNA fragments separated by gel electrophoresis. J Mol Biol 98, 503-507.

Steel, R. \& Walker, T. K. (1957). A comparative study of celluloseproducing cultures and celluloseless mutants of certain Acetobacter spp. J Gen Microbiol 17, 445-452.

Takemura, H., Horinouchi, S. \& Beppu, T. (1991). Novel insertion sequence IS1380 from Acetobacter pasteurianus is involved in loss of ethanol-oxidizing ability. J Bacteriol 173, 7070-7076.

Takemura, H., Horinouchi, S. \& Beppu, T. (1993a). Suppression of ethanol-sensitive mutation of Acetobacter pasteurianus by overexpression of the his1 gene encoding histidinol phosphate aminotransferase. J Ferment Bioeng 76, 224-228.

Takemura, H., Kondo, K., Horinouchi, S. \& Beppu, T. (1993b). Induction by ethanol of alcohol dehydrogenase activity in Acetobacter pasteurianus. J Bacteriol 175, 6857-6866.
Tamaki, T., Fukaya, M., Takemura, H., Tayama, K., Okumura, H., Kawamura, Y., Nishiyama, M., Horinouchi, S. \& Beppu, T. (1991). Cloning and sequencing of the gene cluster encoding two subunits of membrane-bound alcohol dehydrogenase from Acetobacter polyoxogenes. Biochim Biophys Acta 1088, 292-300.

Tayama, K., Fukaya, M., Okumura, H., Kawamura, Y. \& Beppu, T. (1989). Purification and characterization of membrane-bound alcohol dehydrogenase from Acetobacter polyoxogenes sp. nov. Appl Microbiol Biotechnol 32, 181-185.

Wong, H. C., Fear, A. L., Calhoon, R. D. \& 10 other authors (1990). Genetic organization of cellulose operon in Acetobacter xylinum. Proc Natl Acad Sci USA 87, 8130-8134.

Yanisch-Perron, C., Vieira, J. \& Messing, J. (1985). Improved M13 phage cloning vectors and host strains: nucleotide sequences of the M13mp18 and pUC19 vectors. Gene 33, 103-119.

Received 12 April 1996; revised 8 July 1996; accepted 9 September 1996. 